\title{
CIVIL LIABILITY FOR MARINE OIL POLLUTION DAMAGE IN THE BRICS COUNTRIES
}

\author{
DINH THI MY LINH, \\ Peoples' Friendship University of Russia \\ (Moscow, Russia)
}

https://doi.org/10.21684/2412-2343-2020-7-3-29-51

Until the $20^{\text {th }}$ century, most countries around the world focused on developing the benefits of maritime transport and paid little attention to oil pollution from ships. The truth of the matter is that the development of marine transportation was a leading cause of marine pollution. Today, marine oil pollution is considered a dangerous source of contamination of the marine environment, and the oil pollution from ships is the source that draws the greatest concern. This concern clearly is felt by the BRICS countries, whose members, with vast seas adjacent to their landmasses, are keenly interested in preserving and protecting the marine environment against pollution, including marine pollution caused by oil from ships. The BRICS member states are countries with large economies and significant influence on regional and global issues. In recent years they have played a vital role in the world economy in terms of total production, destinations for investment capital and potential consumer markets. Therefore, the development and improvement of the laws of these countries relating to civil liability for marine pollution damage have significance for protecting the marine environment. This paper explores the legal regimes relating to civil liability for marine pollution damage at the international level and in the BRICS member states. It compares the differences in the domestic legislation of the $B R I C S$ countries pertaining to civil liability for marine pollution damage and concludes with recommendations for better implementation.

Keywords: BRICS; marine oil pollution; civil liability; CLC 1992.

Recommended citation: Dinh Thi My Linh, Civil Liability for Marine Oil Pollution Damage in the BRICS Countries, 7(3) BRICS Law Journal 29-51 (2020). 


\section{Table of Contents}

\section{Introduction}

\section{The Legislation System}

\subsection{International Conventions}

\subsection{Member States' Domestic Legislation}

\section{Party/Person Involved}

\subsection{Claiming Party}

2.2. Liable Parties

3. Limitation of Liability and Compulsory Insurance

\subsection{Limitation of Liability}

3.2. Compulsory Insurance

\section{Conclusions and Recommendations}

\section{Introduction}

It is generally accepted that the consequences of oil pollution are not limited to the territory of a specific country but may affect many different countries. In addition, often the losses may exceed the capabilities of individuals, organizations and even nations. To mitigate and minimize the damage, the international community needs to develop common legally binding technical standards and human resources in the field of marine oil pollution. Together with international treaties on cooperation in oil pollution prevention, international treaties on settling compensation for oil pollution from ships have been established, such as the International Convention on Civil Liability for Oil Pollution Damage (CLC) 1969, 1992; International Convention on the Establishment of an International Fund for Compensation for Oil Pollution Damage (Fund Convention), 1971, 1992; International Convention on Liability and Compensation for Damage in Connection with the Carriage of Hazardous and Noxious Substances by Sea (HNS Convention) 1996; and International Convention on Civil Liability for Bunker Oil Pollution Damage (Bunker Convention) 2001.

Pollution at sea often causes large-scale damage, so nations and international organizations must work together to address the damage resulting from oil pollution, in which action by the BRICS countries plays an important role. This paper explores the legal regimes relating to civil liability for marine pollution damage at the international level and in the BRICS members states, from which the author compares the differences in the domestic laws of the BRICS countries pertaining to civil liability for marine pollution damage and offers recommendations for better implementation. 


\section{The Legislation System}

\subsection{International Conventions}

Until the $20^{\text {th }}$ century, most countries around the world focused on developing the benefits of maritime transport, ignoring oil pollution from ships. The truth of the matter is that the development of marine transportation was and remained a leading cause of marine pollution. The main reason why national lawmakers and the international community recognized marine pollution due to oil as an urgent issue that needed to be regulated by law was the oil pollution resulting from the Torrey Canyon disaster in 1967. This was the world's first significant supertanker disaster.' The ship was registered in Liberia with a capacity of 12,300 tons, which made it one of the largest ships in the world at that time, and carried 120,000 tons of crude oil. The ship ran aground off the southwest coast of the United Kingdom and caused a massive oil spill. ${ }^{2}$ This incident can be regarded as the direct cause for the adoption of the International Convention on Civil Liability for Oil Pollution Damage (CLC) 1969 and the International Convention on the Establishment of an International Fund for Compensation for Oil Pollution Damage (Fund Convention) 1971 to provide compensation for pollution damage caused by spills of persistent oil from tankers.

CLC 1969 imposed strict but limited liability on the owners of ships from which oil was discharged for clean-up costs and private damages, and introduced compulsory liability insurance. Fund Convention 1971 set up an international fund which provided compensation over the vessel owner's liability under the CLC, or where the owner is insolvent or not liable under the CLC. Nowadays, CLC 1969 is modified by the Protocol of 1992 to the International Convention on Civil Liability for Oil Pollution Damage 1969 (CLC 1992) and Fund Convention 1971 is amended by the Protocol of 1992 to the International Convention on the Establishment of an International Fund for Compensation for Oil Pollution Damage 1971 (Fund Convention 1992).

Following that, CLC 1992 was amended in 2000 (effective from 1 January 2003). The Convention initially established a process for claiming damages when oil pollution incidents occur. Fund Convention 1992 (continuously) is a supplementary convention to CLC 1992 to create a compensation system for which compensation under CLC 1992 is incomplete. The International Oil Pollution Compensation Fund 1992 (IOPC Fund 1992) was established under Fund Convention 1992 when this convention entered into force on 30 May 1996. Fund Convention 1992 - IOPC Fund 1992 is

\footnotetext{
Grey Hall, Torrey Canyon Alerted the World to the Dangers That Lay Ahead, Professional Mariner, 28 March 2007 (Jun. 10, 2020), available at https://www.professionalmariner.com/torrey-canyon-alerted-theworld-to-the-dangers-that-lay-ahead/; Patrick Barkham, Oil Spills: Legacy of the Torrey Canyon, The Guardian, 24 June 2010 (Jun. 10, 2020), available at https://www.theguardian.com/environment/2010/ jun/24/torrey-canyon-oil-spill-deepwater-bp.

2 'Torrey Canyon' Pollution and Marine Life: A Report by the Plymouth Laboratory of the Marine Biological Association of the United Kingdom (J.E. Smith (ed.), Cambridge: Cambridge University Press, 1968).
} 
a global intergovernmental organization established to run the compensation system according to Fund Convention 1992. Furthermore, Supplementary Fund 2003 was created to supplement the inadequacies of CLC 1992 and Fund Convention 1992.

All of the BRICS member states are currently members of CLC 1992 except Brazil, which is a member of CLC 1969 but not of CLC 1992. Moreover, Russia, India and South Africa are members of Fund Convention 1992, and Fund Convention 1992 is only applicable to Hong Kong Special Administrative Region (SAR) in China. The BRICS countries have not yet participated in Supplementary Fund 2003.

The CLC and Fund regimes applied to "any persistent hydrocarbon mineral oil such as crude oil, fuel oil, heavy diesel oil, and lubricating oil, whether carried on board a ship as cargo or in the bunkers of such a ship," and the Bunker Convention filled the gap in "any residues of such oil" ${ }^{\prime \prime}$ left behind by the CLC and the Fund. Russia, China and Brazil are members of the Bunker Convention.

CLC 1992, Fund Convention 1992 and the Bunker Convention have agreed on a standard compensation for the victims of oil spilled from ships. The basic concepts introduced in these conventions are the principle of strict liability, compulsory insurance and two-tiered compensation with limits.

Moreover, the Convention on Limitation of Liability for Maritime Claims 1976 (LLMC 1976) took the place of the International Convention Relating to the Limitation of the Liability of Owners of Seagoing Ships (which had come into force in 1968). ${ }^{4}$ LLMC 1976 was replaced by the Protocol of 1996 (entry into effect in 2004) and amendments to the protocol in 2012 (entry into force in 2015). Russia and India are members of LLMC 1996, which also applies to Hong Kong SAR in China. The Convention provides for a system of limiting liability. Shipowners and salvors may limit their liability except when

it is proved that the loss resulted from his personal act or omission, committed with the intent to cause such a loss, or recklessly and with the knowledge that such loss would probably result. ${ }^{5}$

Under the Convention, limits on liability are provided for two types of claims claims for loss of life or personal injury and property claims (such as damage to other ships, property or harbor works).

Through the actual operation of transportation the international community recognizes that, apart from the risks and dangers associated with oil, the shipping of

Art. 1(5) of the Bunker Convention 2001.

4 Madeline Burke, Duck and Cover: The Gross Attempts of Limiting Liability in the Titanic, Deepwater Horizon, and Table Rock Lake Accidents, 50(4) Journal of Maritime Law \& Commerce 379 (2019).

5 Convention on Limitation of Liability for Maritime Claims (LLMC) (1976) (Jun. 10, 2020), available at http://www.imo.org/en/About/Conventions/ListOfConventions/Pages/Convention-on-Limitation-ofLiability-for-Maritime-Claims-\%28LLMC\%29.aspx. 
hazardous and toxic substances is also a significant threat to marine pollution. Having recognized the risks and dangers imposed by the common carriage of hazardous and noxious substances (HNS) by sea, the HNS Convention was adopted under the sponsorship of the International Maritime Organization (IMO) in May 1996 to ensure adequate, prompt and effective compensation for damage caused by incidents in connection with maritime transportation of HNS. The Convention provides a liability and compensation regime based on a two-level sanctions system similar to the CLC and Fund conventions for oil pollution. The first compensation level is the responsibility of the shipowner and the second is paid for by the HNS fund (with contributions from the parties with interests in the cargo). The Convention covers not only pollution but also other risks such as fire and explosion caused by hazardous and toxic substances. Moreover, given the nature of the impact of HNS pollution incidents, HNS 1996 goes further by not only covering pollution damage but also risks of fire and explosion, including loss of life and personal injury. However, the HNS Convention has not entered into force due to an insufficient number of ratifications, notwithstanding the fact that the Convention was amended by the Protocol of 2010 (HNS Protocol 2010) specifically to promote its ratification and also to address practical problems that had prevented many states from deciding in favor of ratification. Presently, the HNS Convention of 1996 and the Protocol of 2010 have not yet entered into force. Among the BRICS member states, Russia is the only state which has ratified the Convention.

The leading international conventions regarding civil liability and compensation for marine oil pollution damage are as follow:

- International Convention on Civil Liability for Oil Pollution Damage 1969 [CLC 1969]; Protocol of 1992 to the International Convention on Civil Liability for Oil Pollution Damage 1969 [CLC 1992];

- International Convention on the Establishment of an International Fund for Compensation for Oil Pollution Damage 1971 [Fund Convention 1971], Protocol of 1992 to the International Convention on the Establishment of an International Fund for Compensation for Oil Pollution Damage 1971 [Fund Convention 1992], Protocol establishing an International Oil Pollution Compensation Supplementary Fund 2003 [Supplementary Fund 2003];

- Convention on Limitation of Liability for Maritime Claims 1976 [LLMC 1976], Protocol of 1996 to Amend the Convention on Limitation of Liability for Maritime Claims 1976 [LLMC 1996];

- International Convention on Civil Liability for Bunker Oil Pollution Damage 2001 [Bunker Convention];

- International Convention on Liability and Compensation for damage in connection with the carriage of Hazardous and Noxious Substances by Sea 1996 [HNS 1996] and its 2010 Protocol [HNS Prot 2010].

The participation of the BRICS member states in such international conventions is depicted in Table 1 below. 
Table 1: List of Conventions Acceded to by the BRICS Member States

\begin{tabular}{|l|c|c|c|c|c|c|}
\hline & CLC & CLC & Fund & LLMC & Bunker & HNS \\
& 1969 & 1992 & 1992 & 1996 & 2001 & $1996^{1}$ \\
\hline Brazil & $\checkmark$ & & & & $\checkmark$ & \\
\hline Russia & $\checkmark$ & $\checkmark$ & $\checkmark$ & $\checkmark$ & $\checkmark$ & $\checkmark$ \\
\hline India & $\checkmark$ & $\checkmark$ & $\checkmark$ & $\checkmark$ & & \\
\hline China & $\checkmark$ & $\checkmark$ & $\vee^{2}$ & $\vee^{2}$ & $\checkmark$ & \\
\hline South Africa & $\checkmark$ & $\checkmark$ & $\checkmark$ & & & \\
\hline
\end{tabular}

Notes: (1) HNS 1996 has still not entered into force; (2) Applied only to Hong Kong SAR

It is recognized that most of the BRICS member states have also participated in the leading international conventions regarding civil liability for damage resulting from oil pollution. Thus, there are general rules and regulations for oil pollution compensation claims in the BRICS countries. This facilitates the application of rules to avoid conflict of laws when dealing with compensation issues between the BRICS member states. Nonetheless, there are specific differences between national laws that need to be researched.

\subsection{Member States' Domestic Legislation}

Each country has a separate legal system with its own historical, social and political characteristics. As far as civil liability is concerned for damage resulting from oil pollution, each of the BRICS countries has different laws and regulation systems. Member states' jurisdiction and domestic legislation are essential for the members to implement the international conventions as well as to exercise national jurisdiction to ensure adequate, prompt and effective compensation available to the persons who suffer damage from marine oil pollution.

Laws relating to civil liability and compensation for marine oil pollution are listed in Table 2 below.

Table 2: List of Existing Domestic Laws and Regulations in the BRICS Member States

\begin{tabular}{|l|l|}
\hline Member & Laws and Regulations \\
\hline \multirow{3}{*}{ Brazil $^{6}$} & $\begin{array}{l}\text {-The National Environmental Policy Act of 1981 (Law No. 6,938) } \\
- \text { The Public Civil Action Act of } 1985 \text { (Law No. 7,347) } \\
\end{array}$ \\
\hline
\end{tabular}

\footnotetext{
6 At the federal and state levels - in relation to Brazil, which is federal - these terms are identical.
} 


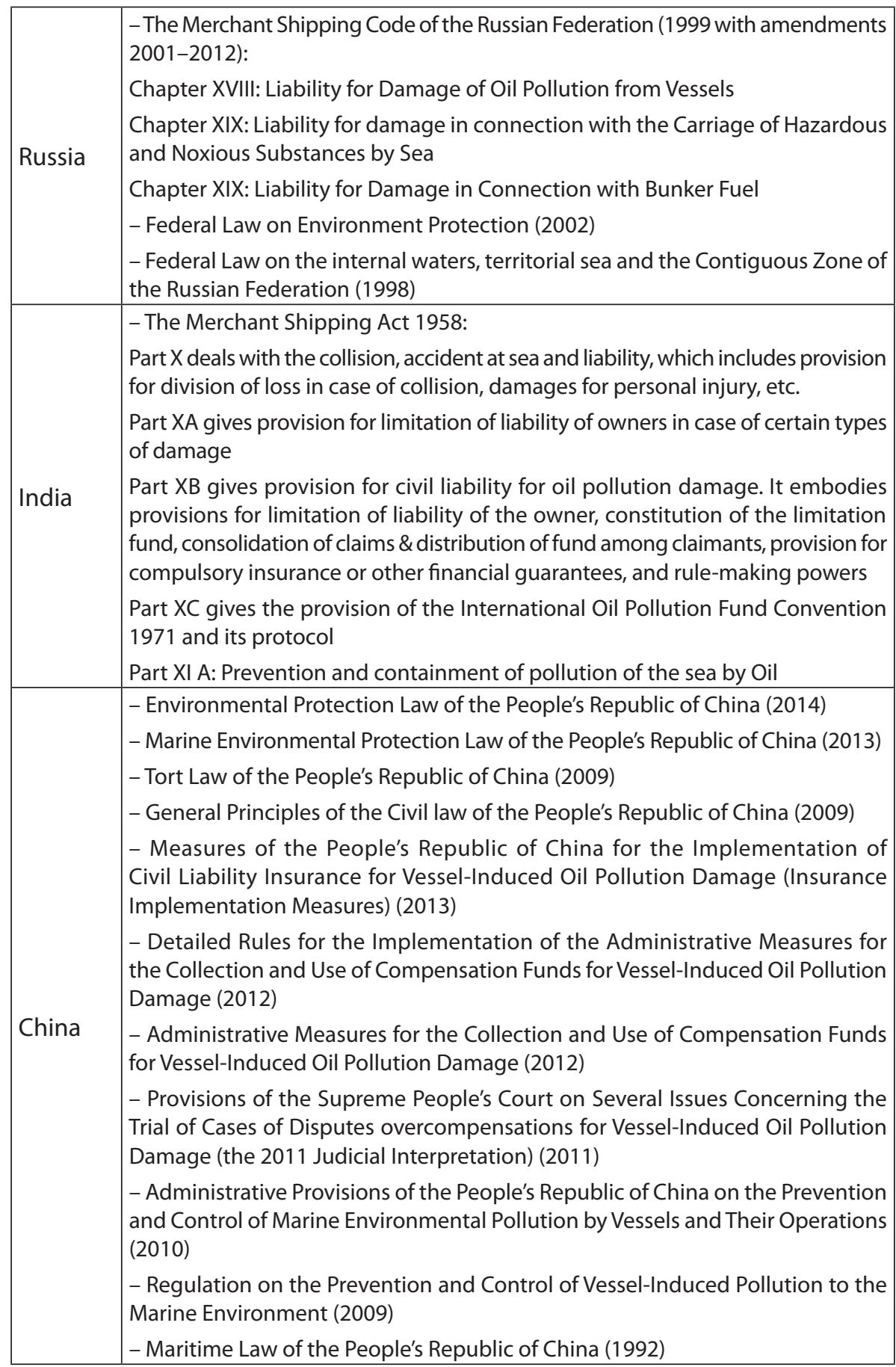




\begin{tabular}{|l|l|}
\hline & - Merchant Shipping (Civil Liability Convention) Act 2013 (Civil Liability Act) \\
& - Merchant Shipping (International Oil Pollution Compensation Fund) Act 2013 \\
South & (Compensation Fund) \\
Africa & - Merchant Shipping (International Oil Pollution Compensation Fund) \\
& $\begin{array}{l}\text { Contributions Act 2013 (Contributions Act) } \\
- \text { Merchant Shipping (International Oil Pollution Compensation Fund) } \\
\text { Administration Act 2013 (Administration Act) }\end{array}$ \\
\hline
\end{tabular}

Among the BRICS countries, India and South Africa are Commonwealth countries, and in addition to having transparent rules governing civil liability and compensation for damage caused by marine oil pollution, these countries also have a specific case system that regulates this issue. The sources of law of civil liability for marine oil pollution in India and South Africa are international customs, international conventions, decisions of the countries' courts and the decisions of the court of the foreign countries which are recognized by their courts. In Russia, there are relevant regulations in the Merchant Shipping Code of the Russian Federation which cover oil and HNS pollution from vessels. In China and Brazil, there is currently no special law to regulate compensation for oil pollution from ships; however, some regulations exist that may be said to constitute a legal system in this respect.

Each country's legal system has established regulations governing civil liability and compensation for damage due to oil pollution at sea. In different ways, each state also codifies international treaties to which it is a signatory. It is hard to assess whether the current legal systems (not only national law but also international law) have achieved the highest efficiency in terms of adequacy, timeliness and effective compensation, because the damage to the sea from oil is difficult to determine and confirm at specific levels and based on uniform calculations.

\section{Party/Person Involved}

In general, there are two parties involved in a case concerning civil liability and compensation for marine oil pollution: one party is liable for compensation (liable party); the other party has suffered damage and has a right to a claim (claiming party). The BRICS member states have similarities in the regulations on parties entitled to claim, but there are also differences regarding liable parties.

\subsection{Claiming Party}

The consequences of an oil spill are serious for nature and people alike. First, it is possible to immediately recognize the affected marine environment, the negative impact on flora and fauna, and that natural environment restoration measures will be required. In addition, oil pollution of the sea, by harming beaches, will affect the tourism industry and the owners and staff of coastal hotels, resorts and 
entertainment areas. Marine tourism service providers will also suffer economic losses. Furthermore, the fishing industry will be directly affected, as will owners and charterers of ships which must be diverted from the contaminated area, thus delaying the transportation of seaborne goods and thereby increasing costs.

Overall, the victims of an oil spill are many and varied. As regards the person who has the right to claim damages from marine oil pollution, no relevant international convention specifically regulates this matter. The members states of BRICS follow the same general principle according to which any person who suffers losses from marine oil pollution is entitled to claim damages, including the competent authorities acting on behalf of the state, organizations and individuals.

\subsection{Liable Parties}

The regulations relating to liable parties are clearly governed by international conventions and national laws. Article III of CLC 1969, and CLC 1992 as well, stipulate that the owner of a ship shall be liable for any pollution damage caused by the ship as a result of an incident. ${ }^{7}$ On the other hand, in the Bunker Convention the shipowner is defined more broadly than in the CLC:

The owner, including the registered owner, bareboat charterer, manager, and operator of the ship. ${ }^{8}$

Each BRICS country has different specific definitions of the shipowner, as follow. 1. Brazil

The Brazilian Constitution (in force since 1988) provides that the environment is public property, thus the environment must be maintained for present and future generations, allowing strict environmental laws to be passed. This permits strict environmental legislation to be passed at the federal and state levels. ${ }^{9}$ Hence, the "polluter pays" principle applies under Brazilian civil law, namely anyone who causes damage to the environment, even indirectly, is considered to be a polluter and consequently is responsible for paying compensation for damage to the environment. ${ }^{10}$ Shipowners are therefore strictly liable for any oil pollution that escapes or is discharged from their vessels. This includes the pollution clean-up costs and any property damage claims (which may include loss of income/business-

International Convention on Civil Liability for Oil Pollution Damage (1992) (Jun. 10, 2020), available at http://library.arcticportal.org/1617/1/Liability_Convention_1992.pdf.

8 Art. 1(3) of the Bunker Convention 2001.

9 Ursula O'Donnel, Introduction of a New Right to Limit Liability in Brazil-Implications for the Offshore Sector, Latin American Bulletin (December 2015) (Jun. 10, 2020), available at http://www.standard-club.com/ media/1965931/latin-american-bulletin-intoduction-of-a-new-right-to-limit-liability-in-brazil.pdf. 
interruption type losses) that arise as a result. Law No. 7,652 of 3 February 1988, as amended by Law No. 9774 of 21 December 1988, provides that the shipowner is "an individual or legal entity who, in its name and under its responsibility, prepares the ship for use, whether or not for navigation on its account."11

\section{Russia}

Pursuant to Article 8 of the Merchant Shipping Code of the Russian Federation, the definition of "shipowner" is "a person who operates the vessel in his own name, whether being the owner of it or on any other lawful basis." Article 1079 of the Civil Code establishes that only the shipowner and no other persons (the possessor of the ship, his employees) is liable for damage caused by pollution. The Merchant Shipping Code does not exempt the owner of the vessel (the insurer of his liability or persons who provided other financial support) from liability for damage if the vessel left his possession as a result of unlawful actions of other persons, and does not place liability on such persons. In some cases, such actions may fall under the provisions of Article 317 of the Merchant Shipping Code, exempting the owner of the vessel from liability for other reasons (this will be covered in section 3.1. below).

\section{India}

In the Merchant Shipping Act, Part XB Civil Liability for Oil Pollution Damage, Section $352 \mathrm{H}$ states that the shipowner is the person registered as the owner of the ship and includes the operator who, for a particular period of time, is in charge of the ship and the master of the ship. Indian law also anticipates that other events may actually occur. If not registered, then the shipowner is the person owning the ship or, in the case of a tanker owned by a foreign state, the person registered in that state as the operator of the ship.

\section{China}

China joined CLC 1992 on 5 January 2000 and the Bunker Convention on 9 March 2009. China has codified the provisions of these conventions in its national legal system. Therefore, the definition of "shipowner" in China follows these conventions when the respective convention applies. When none of the conventions applies, the ownership of a ship means the shipowner's rights to lawfully possess, utilize, profit from and dispose of the ship under his ownership. ${ }^{12}$ Paragraph 1 of Article 89 of the Marine Environment Protection Law of China regulates that the person causing environmental pollution damage will remove that pollution and be liable for compensation for such damage.

\section{South Africa}

Since South Africa is a member of CLC 1992 (as of 1 October 2005), the definition of liable parties follows the regulation of the Convention. As mentioned above,

\footnotetext{
11 Art. 16 of the Law of Brazil No. 7,652/1988.

12 Maritime Code of the People's Republic of China (1992), Art. 7 (Jun. 10, 2020), available at http://www. ilo.org/dyn/natlex/docs/ELECTRONIC/31944/108012/F628338406/CHN31944\%20Eng.pdf.
} 
CLC 1992 provides that the owner of a polluting ship is the responsible person in the case of oil pollution damage. ${ }^{13}$ The Convention further provides that the owner is the "person or persons registered as the owner of the ship or, in the absence of registration, the person or persons owning the ship."14 However, in the case of a ship owned by a state and operated by a company that is registered as the ship's operator in that state, the owner shall mean such a company.

\section{Limitation of Liability and Compulsory Insurance}

\subsection{Limitation of Liability}

The consequences of maritime oil pollution are diverse and complex. Moreover, compensation and remediation sometimes go beyond the ability of the shipowner, even the ability of the nation. The consequences of maritime oil pollution can be broken down into two categories: damage to the environment and loss of profit (for example, to the fishing, tourism and transportation industries). In terms of the main conventions regarding this issue (mentioned above), pollution damage includes both categories of damage. Of course, liability for maritime oil pollution also covers both categories.

Limitation of liability was initially based upon the concept of "abandonment," which also formed the basis for the International Convention for the Unification of Certain Rules Relating to the Limitation of the Liability of Owners of Sea-going Vessels 1924. Thus, the limitation amount was based mainly on the value of the ship post-casualty. This convention was the first to introduce tonnage-related limits, which were then followed by LLMC 1976. ${ }^{15}$

The liability of the shipowner is strict, that is, if a causal link can be established between the oil spill and the pollution damage, the shipowner shall be liable for the pollution damage, even though there are some exceptions. According to Article III(2) of CLC 1996 and Article 3(3) of the Bunker Convention, no liability shall attach to ownership if proven that:

(a) the damage resulted from an act of war, hostilities, civil war, insurrection or a natural phenomenon of an exceptional, inevitable and irresistible character; or

(b) the damage was wholly caused by any act or omission done with intent to cause damage by a third party; or

(c) the damage was wholly caused by the negligence or other wrongful act of any government or other authority responsible for the maintenance of lights or other navigational aids in the exercise of that function.

13 Art. III(1) of the CLC 1992.

14 Art. I(3) of the CLC 1992.

15 A Look into the Convention on Limitation of Liability for Maritime Claims, SAFETY4SEA, 19 March 2018 (Jun. 10, 2020), available at https://safety4sea.com/a-look-into-the-convention-on-limitationof-liability-for-maritime-claims/. 
Furthermore, when considering the actual circumstances, what must be taken into account is a situation which is not entirely the fault of the shipowner. If the shipowner demonstrates that the pollution damage resulted in whole or in part either from an action or from an omission that was done with intent to cause damage by the person suffering the damage or from the negligence of that person, the shipowner may be freed wholly or partially from liability to such person. ${ }^{16}$

The shipowner's limitation liability is one of the most controversial topics within the international oil pollution regime. Nowadays at the international level, the compensation regimes for persistent oil pollution damage from tankers have a three-tier system, as follows.

First-tier. The International Convention on Civil Liability for Oil Pollution Damage 1992: A shipowner's liability limit under the CLC depends on the size of the ship. Article V of CLC 1992 stipulates limitation amounts in terms of which the shipowner may cap his liability. However, the limited amount must always be increased to take into account inflation, as well as to keep up with changing circumstances.

The limitation amounts refer to units of account. CLC 1992 explains that units of account apply to Special Drawing Rights (SDRs) ${ }^{17}$ as set by the International Monetary Fund (IMF), and they are to be converted into national currency on the date of the constitution of the fund. ${ }^{18}$ The calculation of the aggregate amount of limitation per incident was as follows: ${ }^{19}$

(+) Three million SDRs for a ship not exceeding 5,000 tons

(+) for a ship in excess of 5,000 tons, 3 million SDRs together with 420 SDRs for each additional ton of its tonnage in excess of 5,000 tons up to a maximum of 59.7 million SDRs.

The above amounts were amended in a protocol in October 2000. The quantities at present are:

(+) 4,510,000 SDRs for a ship not exceeding 5,000 tons; and

(+) for a ship in excess of 5,000 tons 4,510,000 SDRs together with 631 SDRs for each additional ton of its tonnage in excess of 5,000 tons up to a maximum of $89,770,000$ SDRs.

Second tier. The International Convention on the Establishment of an International Fund for Compensation for Oil Pollution Damage 1992.

The second tier of the compensation scheme applies where the compensation available from the tanker owner is insufficient to pay the full compensation costs. Fund Convention 1992 governs the second tier.

16 Art. 3(4) of the Bunker Convention 2001.

17 Special Drawing Rights: an international reserve asset created by the IMF in 1969 to supplement the existing official reserves of member countries.

18 Art. V(9)(a) of the CLC 1992.

19 Art. V(1)(a)-(b) of the CLC 1992. 
Fund Convention 1992 set up the International Oil Pollution Compensation Fund 1992 (IOPC Fund 1992) to compensate victims who could not receive full compensation under CLC 1992. Contributions finance IOPC Fund 1992 levied on any entity or person who has received more than 150,000 tons of persistent oil after sea transport per the calendar year in countries that are parties to Fund Convention 1992.

The total compensation amount available for an incident under two stages is 203 million SDRs.

Third tier. When damage exceeds the amount payable in the above two schemes, there is a third level compensation under Supplementary Fund 2003.

The Supplementary Fund Protocol set up the International Oil Pollution Compensation Supplementary Fund (Supplementary Fund 2003) to compensate victims who could not receive full compensation under CLC 1992 and Fund Convention 1992. The total compensation amounts available under the three tiers combined is 750 million SDRs.

Supplementary Fund 2003 is financed in a similar way as Fund Convention 1992, that is, by contributions levied on public or private entities in receipt of more than 150,000 tons of contributing oil after sea transport per the calendar year in countries that are parties to the Supplementary Fund Protocol.

However, the BRICS countries are not currently members of Supplementary Fund 2003. As mentioned in Table 1 above, with the exception of Brazil, which is not a member of CLC 1992, the remaining countries in the BRICS (Russia, India, China, and South Africa) are all members of CLC 1992, so these countries have the limitation of liability in accordance with the provisions of CLC 1992. Moreover, Brazil, Russia and China are members of the Bunker Convention. Pursuant to Article 6 of the Convention, as regards limitation of liability:

Nothing in this Convention shall affect the right of the shipowner and the person or persons providing insurance or other financial security to limit liability under any applicable national or international regime, such as the Convention on Limitation of Liability for Maritime Claims, 1976, as amended.

Specific regulations of the BRICS member states are listed below.

1. Brazil

Although CLC 1969 is in force in Brazil, and in this convention there are limitations on liability of shipowners for oil pollution, in fact, there is no situation where CLC 1969 has been applied in Brazil. CLC 1969 has not been implemented by Brazilian courts; not a single decision providing for the application of the limitation of liability, defense of liability or the channeling of liability to the shipowner for environmental damage has appeared. ${ }^{20}$ Brazilian law provides for administrative, civil and criminal

20 Raphael M. Vianna Gonçalves, Chapter 8. Offshore Oil Spill and Punitive Damages in Brazil in Richesses et misères des océans: Conservation, Ressources et Frontières 233 (P. Chaumette (coord.), GOMILEX, 2018) (Jun. 10, 2020), also available at https://hal.archives-ouvertes.fr/hal-01983699/document. 
liability. The Civil Code does not provide for a limitation of civil liability although it establishes that anyone who causes damage to another party must fully compensate for the damage caused.

Regarding environmental civil liability, Article 225 of the Brazilian Federal Constitution stipulates that the polluter must remedy the damage caused to the environment and to the victims. The civil liability of shipowners in Brazil is strict. It is not possible to limit liability for damage to the environment and third parties caused by pollution. There is no need to prove fault or willful misconduct on the part of the owners, assuming that the causal link between the polluting activity performed by the polluter and the environmental damage is verified. Anyone who contributes (even indirectly) to environmental damage is considered a polluter.

Regarding the amounts of indemnity, it is essential to point out that Brazilian law does not provide for punitive damages; therefore, indemnity is limited to the direct damage suffered, including the actual losses and reasonable loss of earnings. However, indirect damage or consequential losses are expressly excluded, unless otherwise agreed by the parties. It is also important to point out that direct damage includes both material damage and moral damage. Nevertheless, it is possible under Brazilian law for the parties to limit their liability towards each other under a contract.

\section{Russia}

Chapter XVIII of the Merchant Shipping Code of the Russian Federation, which is based on the CLC Convention, gives provisions on liability for oil pollution and the limitation of liability, and Chapter XX.1 of the Code puts into effect the provisions of the Bunker Convention. Pursuant to these provisions, the owners of all vessels of the gross tonnage of 1,000 tons and above have the right to limit their liability, which is also consistent with the provisions of the Convention on Limitation of Liability for Maritime Claims 1996 (LLMC 1996). Individually, the limitation of liability is regulated in Chapter XXI of the Merchant Shipping Code (Arts. 354-366), where the provisions of the Convention on Limitation of Liability for Maritime Claims are implemented. In 2016, the applicable liability limits were those set by the 2012 Amendments to LLMC 1996, which are included under Article 359 of the Merchant Shipping Code. ${ }^{21}$

Article 331 of the Merchant Shipping Code regulates on the Limitation of the Liability of a Shipowner, as follows.

A shipowner shall be entitled to limit his liability towards an incident by the total sum calculated in the following way: 10 million units of account for a ship with tonnage of not more than 2,000 tons. For a ship with tonnage of over 2,000 tons it is necessary to add the following units of account to the amount, indicated in the second paragraph of Article 331, for each subsequent ton of capacity: for a ship of 2,001 to 50,000 tons $-1,500$ units of account; for a ship with a displacement of

21 Konstantin Krasnokutskiy, Russia: Shipping Laws and Regulations 2020, ICLG, 6 August 2020 (Jun. 10, 2020), available at https://iclg.com/practice-areas/shipping-laws-and-regulations/russia. 
more than 5,000 tons - 360 units of account; provided that the total sum under the circumstances exceeds 100 million units of account.

In opposition to the provisions of the CLC Convention, Russian legislation prescribes compensation for marine oil pollution damage (or other pollutants) based on a formula in which the size of the compensation depends on the amount of oil spilled. Nevertheless, in cases within the scope of the Convention, the Convention shall prevail over national legislation.

3. India

India has adopted national laws to international law, namely CLC 1992, to which it is a party. Section $352 \mathrm{~J}$ of the Merchant Shipping Act provides the following.

Limitation of liability

(1) Save as otherwise provided in sub-section (2), the owner may limit his liability under Section $352 \mathrm{I}$ in respect of any incident to an aggregate amount of 1 (a) one hundred and thirty-three Special Drawing Rights for each ton of the ship's tonnage; or (b) fourteen million Special Drawing Rights, whichever is lower.

(2) Where any incident causing pollution damage occurs as a result of the actual fault of the owner, he shall not be entitled to limit his liability under sub-section (1).

\section{China}

With regard to the limitation of liability for marine oil pollution damage caused by vessels carrying persistent oil in bulk to sea areas under Chinese jurisdiction, the provisions of the international treaties concluded or acceded to by China shall apply. For specific oil pollution caused by ship for which neither CLC 1992 nor the Bunker Convention applies, for example, pollution caused by non-persistent oil carried on board a ship (including tankers) as cargo, the provisions of Chapter 11 of the China Maritime Code may be applied for the limitation of liability of the liable party. ${ }^{22}$

Article 210 of the China Maritime Code stipulates the amount of limitation.

1. In respect of claims for loss of life or personal injury:

(1) 333,000 Units of Account for a ship with a gross tonnage ranging from 300 to 500 tons;

(2) For a ship with a gross tonnage in excess of 500 tons, the limitation under (1) above shall be applicable to the first 500 tons, and the following amounts in addition to that set out under (1) shall be applicable to the gross tonnage in excess of 500 tons:

For each ton from 501 to 3,000 tons: 500 Units of Account;

For each ton from 3,001 to 30,000 tons: 333 Units of Account;

For each ton from 30,001 to 70,000 tons: 250 Units of Account;

For each ton in excess of 70,000 tons: 167 Units of Account.

22 NOWPAP MERRAC, Legislation and Practices Related to Civil Liability and Compensation for Marine Pollution Damage in the NOWPAP Member States, MERRAC Technical Report No. 10 (2015) (Jun. 10, 2020), available at https://wedocs.unep.org/bitstream/handle/20.500.11822/26218/legislation_civil_ liability.pdf? sequence $=1$. 
2. In respect of claims other than that for loss of life or personal injury:

(1) 167,000 Units of Account for a ship with a gross tonnage ranging from 300 to 500 tons;

(2) For a ship with a gross tonnage in excess of 500 tons, the limitation under (1) above shall be applicable to the first 500 tons, and the following amounts in addition to that under (1) shall be applicable to the part in excess of 500 tons:

For each ton from 501 to 30,000 tons: 167 Units of Account;

For each ton from 30,001 to 70,000 tons: 125 Units of Account;

For each ton in excess of 70,000 tons: 83 Units of Account.

Here, it is clear that there is a difference between the "claims related to other than personal injury or loss of life" and "claims related to personal injury or loss of life": the limitation amount for "claims related to other than personal injury or loss of life" is half of the limitation amount for "claims related to personal injury or loss of life."

Therefore, the limitations stipulated in Article V(1) of CLC 1992 and its 2002 Amendment shall apply to oil pollution damage caused by vessels carrying persistent oil in bulk (except for oil pollution damage that results from the spillage of non-persistent bunker oil from tankers carrying persistent oil), whereas limitations that are provided in Article 210(2) of the Chinese Maritime Code shall apply to oil pollution damage caused by vessels carrying non-persistent oil in bulk, and non-tanker vessels, as well as oil pollution damage caused by the spillage of non-persistent bunker oil from tankers carrying persistent oil. ${ }^{23}$

\section{South Africa}

Just as other countries that are members of CLC 1992 do, South Africa directly applies the standards in the Convention. When applied to specific cases, it is necessary to convert SDRs into South Africa's national currency, and the determination of the exchange rate is a responsibility of the Minister of Transport. Specifically, Article 15 of the Merchant Shipping (Civil Liability Convention) Act 2013 states that,

The Minister may make regulations: regarding the conversion of the amounts of money referred to in paragraph 1 of Article V of the CLC 1992 into amounts of money expressed in the South African currency.

\subsection{Compulsory Insurance}

In most countries and even at the international level, in order to meet potential liability risks, a shipowner is required to have compulsory insurance or financial security. Maritime insurance has a particularly vital role to play in the development of transportation, for shipowners and also for nations. It is the means

23 Bingying Dong \& Ling Zhu, Civil Liability and Compensation for Damage in Connection with the Carriage of Hazardous and Noxious Substances: Chinese Perspective, 50(2-3) Ocean Development \& International Law 209 (2019) (Jun. 10, 2020), also available at https://www.tandfonline.com/doi/abs/10.1080/00 908320.2019 .1582609 . 
by which those who own or are interested in or responsible for a maritime property seek to protect themselves in respect of loss of or damage to it and against liabilities to other parties falling upon them arising out of their ownership, interest or responsibility. ${ }^{24}$

Under the Civil Liability Convention (CLC 1992), with the purpose of covering a shipowner's liability for pollution damage under the Convention, the owner of a ship registered in a Contracting State and carrying more than 2,000 tons of persistent oil in bulk as cargo must maintain insurance (or other financial security). Insurance must also be applied to any ship, wherever registered, entering or leaving a port or terminal within the territory of a Contracting State. A Contracting State must certify insurance, and ships must carry a state-issued certificate confirming that the ship is so insured (or covered by other financial security). ${ }^{25}$

Similar to the regulation on limitation of liability mentioned above, Brazil does not participate in CLC 1992, but the remaining members of BRICS do, and they also follow the provisions on compulsory insurance stated in CLC 1992.

Moreover, although HNS 1996 has still not entered into force, Russia has joined the Convention and codified its rules relating to compulsory insurance and incorporated them into national regulations.

Specific regulations of the BRICS member states are listed below.

1. Brazil

Federal Law 8.374/1991 stipulates that all ships registered before Brazil's port captaincies must buy DPEM insurance ${ }^{26}$ (compulsory insurance for anyone who owns a boat or ship). Theoretically, uninsured vessels are not eligible for licensing and therefore not allowed to sail in Brazilian waters.

The reality however is that oil spills occur frequently and the consequences of oil pollution are often very serious, and thus a large amount of money is required to pay compensation. Insurance companies cannot meet such indemnification obligations. Therefore, in Brazil, companies providing DPEM insurance no longer operate. In addition, according to Navy Instruction 04/2016 of Federal Law 13.313/2016, if no insurers offer policies, the Maritime Authority cannot demand that vessel owners purchase the insurance. Hence DPEM insurance is no longer compulsory. And thus

24 Howard B. Hurd, The Law and Practice of Marine Insurance Relating to Collision Damages and Other Liabilities to Third Parties xxi ( $2^{\text {nd }}$ ed., London: I. Pitman, 1952).

25 International Oil Pollution Compensation Funds, Guidance for Member States: Consideration of the Definition of 'Ship' (2016 Edition) (Jun. 10, 2020), available at https://www.iopcfunds.org/wp-content/ uploads/2018/04/IOPC_definition_of_ship_ENGLISH_web.pdf.

26 Iwam Jaeger \& Bernardo Silva de Senna, Mandatory Insurance and Maritime Accidents: Law Versus Reality, International Law Office, 11 October 2017 (Jun. 10, 2020), available at https://www.internationallawoffice. com/Newsletters/Shipping-Transport/Brazil/Kincaid-Mendes-Vianna-Advogados/Mandatoryinsurance-and-maritime-accidents-law-versus-reality. 
vessels operate without DPEM insurance despite the National Insurance Brokers Federation's and the Federal Insurance Regulatory Authority's best efforts to see that policies are offered.

\section{Russia}

In Russia, shipowners of vessels carrying HNS are required to have insurance or other financial guarantees. ${ }^{27}$ Article 334 of the Merchant Shipping Code of the Russian Federation provides:

With the purpose of ensuring the liability of the shipowner when damage occurs, the owner of the ship actually carrying dangerous and harmful substances shall effect insurance or provide any other financial security of liability (a bank guarantee or a guarantee of any other credit organization) to the amount equal to the limit of his liability in accordance with Article 331 of this Code. ${ }^{28}$

\section{India}

Indian law also applies in accordance with CLC 1992 in Section 352 N of the Merchant Shipping Act, and any certificate issued outside India by a competent authority is accepted at any port or place in India. ${ }^{29}$ Without such a certificate, the ship is not permitted to enter or leave an Indian port or site in the territorial seas India claims.

Section $352 \mathrm{~N}$ regulates compulsory insurance or other financial guarantees:

The owner of every Indian ship which carries 2,000 tons or more oil in bulk as cargo shall, in respect of such ship, maintain an insurance or other financial security. In particular, an amount is calculated in two ways, and the lower is chosen:

- one hundred and thirty-three Special Drawing Rights for each ton of the tonnage of the ship, or

- fourteen million Special Drawing Rights.

In respect of every Indian ship which maintains insurance or other financial security, there shall be issued by the Director-General a certificate in such form and giving such particulars as may be prescribed.

4. China

China has established a compulsory insurance system, which, together with liability rules, constitutes the first tier of compensation for oil pollution. The Marine

27 Marine Insurance and Accidents in Russia, Lexology, 11 February 2019 (Jun. 10, 2020), available at https://www.lexology.com/library/detail.aspx?g=060250bb-b253-4509-9dca-9010f67afcca.

28 Merchant Shipping Code of the Russian Federation No. 81-FZ of 30 April 1999 (Jun. 10, 2020), available at https://www.wto.org/english/thewto_e/acc_e/rus_e/WTACCRUS33A1_LEG_15.pdf.

29 Sec. 3520 of the Merchant Shipping Act [India]. 
Environment Protection Law 1999 and the Amended Regulations provide the general principles of compulsory insurance for oil pollution damage from ships. Specific issues, such as the subject matter insured, insured value, competent insurance institution, insurance certificates, direct action against the insurer and defense of the insurer shall accordingly be subject to Measures of the People's Republic of China for the Implementation of Civil Liability Insurance for Vessel-Induced Oil Pollution Damage and the Judicial Interpretation. Whereby,

for the vessels carrying oil substances and vessels carrying non-oil substances with a gross tonnage of not less than 1,000 gross tons which are navigating within the sea areas of the People's Republic of China, the owners thereof shall buy civil liability insurance for vessel-induced oil pollution damage or obtain corresponding financial guarantee in accordance with these Measures. ${ }^{30}$

Consistent with the Prevention Regulation, this rule confirms the insurance requirement for owners for three types of ships: those carrying as bulk cargo either (1) persistent or (2) non-persistent oil, or (3) more than 1,000 gross tons of non-oil substances. ${ }^{31}$ We can easily notice that compared with the requirement under CLC 1992, the Chinese law on oil pollution insurance is a stricter standard. According to Article 53 of the Amended Regulations, owners of all vessels navigating the marine areas under Chinese jurisdiction - except for ships of less than 1,000 gross tons of nonoil cargo - shall be required to maintain insurance or additional financial security. ${ }^{32} \mathrm{At}$ the same time, Article 8 of the Judicial Interpretation stipulates that claimants have the right to directly claim for oil pollution damage against the insurer or financial guarantor. The insurance company could be exempt from its liability if the pollution damage is caused by any willful misconduct of the shipowner himself. However, in all cases the insurance company cannot reject a claim for the defense which he might have been entitled to invoke in a proceeding brought against him by the owner.

\section{South Africa}

To internalize the rules from CLC 1992, South Africa has enacted the Merchant Shipping (Civil Liability Convention) Act 2013, whose Article 6(1) provides:

30 Measures of the People's Republic of China for the Implementation of Civil Liability Insurance for VesselInduced Oil Pollution Damage (Ministry of Transport of the People's Republic of China, 19 August 2010, amended on 31 August 2013, in force 31 August 2013), Art. 2.

31 Id. Art. 4.

32 Ports and the Environment: Maritime Policy and Management. Chapter 4: Further Thinking on the Compensation System for Vessel-Source Oil Pollution in China (M. Luo \&T.L. Yip (eds.), London: Routledge, 2016) (Jun. 10, 2020), also available at https://www.taylorfrancis.com/books/e/9781315673639/ chapters/10.4324/9781315673639-11. 
Paragraph 1 of Article VII of the 1992 Liability Convention, in so far as it relates to the Republic, must be construed as requiring the owner of a ship registered in the Republic to maintain the insurance or other financial security referred to in that paragraph.

It can thus be understood that South Africa directly applies the compulsory insurance standards of CLC 1992.

In order to ensure the actual implementation of compulsory insurance, Section 11 of the Merchant Shipping (Civil Liability Convention) Act 25 of 2013 states that if a ship enters or leaves a port in the Republic, or arrives at a port in the Republic, or arrives at a terminal in the territorial waters of the Republic without having on board the ship the relevant insurance certificate, both the master and the owner of the ship will be guilty of an offense and liable on conviction of a fine. ${ }^{33}$

\section{Conclusions and Recommendations}

There are a number of international regimes for marine oil pollution compensation and which address limitation of liability, such as the International Convention on Civil Liability for Oil Pollution Damage, International Convention on the Establishment of an International Fund for Compensation for Oil Pollution Damage, International Oil Pollution Compensation Supplementary Fund and International Convention on Civil Liability for Bunker Oil Pollution Damage. Although not all of the BRICS member states have acceded to these conventions, the conventions are generally well incorporated into the laws of those member states that are parties to the conventions and provide a joint base for a better understanding of the laws and practices of the BRICS member states.

From the statistics presented, the author concludes that in the BRICS countries there are certain similarities in parties involved in the regulations on civil liability for marine oil pollution damage yet also many differences, and most noticeable is the difference between Brazil and the rest of the BRICS countries in limitation of liability and compulsory insurance.

In fact, in Brazil the resolution of the case involving marine oil pollution is very complicated. This occurs because there is no clear identification of who has the authority to resolve the issue. This means the intricate, unnecessary involvement of different state and federal government agencies, which leads to overlapping of responsibility in the areas of law on liability for marine oil pollution (e.g. administrative, civil and criminal law) and inconsistencies in the quantifying of damages and fines. In principle, the Maritime Authority is authorized to impose fines. Yet, in some instances

33 Merchant Shipping (Civil Liability Convention) Act 25 of 2013 (Jun. 10, 2020), available at https://www. gov.za/sites/default/files/gcis_document/201409/37146gon994act25-2103.pdf. 
federal and state environmental agencies can also impose fines, which may result in the application of multiple administrative penalties for the same incident. ${ }^{34} \mathrm{All}$ of this adds to the uncertainty and ambiguity surrounding the shipowner's liability for pollution in Brazil. Impediments surrounding shipowners' liability for marine oil pollution damage in Brazil is the result of the complex legal framework that is in its early stages of development and has gone in a different direction than internationally accepted regimes such as the International Convention on Civil Liability for Oil Pollution Damage.

Currently, BRICS member states are in the process of promoting and expanding areas of cooperation with each other, including environmental protection, transport and insurance. This has a positive impact on improving the efficiency and adequacy of the compensation procedure for oil damage because cooperation in these areas has a constructive influence on civil liability for marine oil pollution, especially regarding compensation in this issue. Additionally, if the BRICS countries jointly set up a legal system governing civil liability for marine oil pollution, it will also be a bridge to making cooperation in this field more accessible.

The clear solution is to minimize the differences between the regulations of the BRICS countries, as mentioned above, especially between Brazil and the BRICS member states in limitation of liability and compulsory insurance. For example, cooperation in the field of insurance can resolve the present situation of compulsory insurance regulations for ships which is not enforced in Brazil. However, if insurance companies from other countries are allowed to provide insurance services for ships in Brazil, then the legal system in Brazil for determining damages and fines must be changed in a specific way and not overlap jurisdiction between the relevant areas.

Furthermore, the BRICS countries may consider forming an organization to respond to oil pollution in their waters. Although the BRICS countries do not share the same waters, the establishment of such an organization may provide more timely responses and cooperation in the event of an oil spill, especially in relation to the member states, such as, for example, if one country's oil tanker causes environmental pollution in the waters adjacent to another member state. And in order to speed up the process of remedying and compensating damage, the BRICS countries may also consider establishing a compensation fund among their members.

Finally, the BRICS countries may also consider having specific fora to discuss issues relating to marine oil pollution, including each member state's domestic laws and practices, develop detailed guidance and rules, and make a collective effort to facilitate the compensation process on a regular basis.

34 Oil Pollution in Brazil, Steamship Mutual (February 2010) (Jun. 10, 2020), available at https://www. steamshipmutual.com/publications/Articles/BrazilPollution0210.html\#_ftn3. 


\section{References}

'Torrey Canyon' Pollution and Marine Life: A Report by the Plymouth Laboratory of the Marine Biological Association of the United Kingdom (J.E. Smith (ed.), Cambridge: Cambridge University Press, 1968).

Burke M. Duck and Cover: The Gross Attempts of Limiting Liability in the Titanic, Deepwater Horizon, and Table Rock Lake Accidents, 50(4) Journal of Maritime Law \& Commerce 379 (2019).

Gauci G. Compulsory Insurance Under EC Directive 2009/20/EC - An Adequate Solution for Victims, or Is It Also Time for the Abolition of Maritime Limitation of Liability and the Establishment of an International Fund as an Insurer of Last Resort?, 45(1) Journal of Maritime Law \& Commerce 77 (2014).

Glazewski J. Environmental Law in South Africa $\left(2^{\text {nd }}\right.$ ed., Durban and London: Butterworths, 2000).

Hao H. Prospect of China's Accession to the 1992 International Convention on the Establishment of an International Fund for Compensation for Oil Pollution Damage, 30(2) China Oceans Law Review 96 (2019).

Hiscox S. A Critical Examination of South African Law on Civil Liability for Oil Pollution Damage from Ships (University of Cape Town, 1993).

Hurd H.B. The Law and Practice of Marine Insurance Relating to Collision Damages and Other Liabilities to Third Parties (2 ${ }^{\text {nd }}$ ed., London: I. Pitman, 1952).

Kashubsky M. Marine Pollution from the Offshore Oil and Gas Industry: Review of Major Conventions and Russian Law (Part I), 151 Maritime Studies 1 (2006). https:// doi.org/10.1080/07266472.2006.10878832

Kunreuther H. \& Freeman P. Insurability, Environmental Risks and the Law in The Law and Economics of the Environment 302 (A. Heyes (ed.), Cheltenham: Edward Elgar, 2001).

Ports and the Environment: Maritime Policy and Management. Chapter 4: Further Thinking on the Compensation System for Vessel-Source Oil Pollution in China (M. Luo \& T.L. Yip (eds.), London: Routledge, 2016). https://doi.org/10.4324/9781315673639 2016

Prevention and Compensation of Marine Pollution Damage: Recent Developments in Europe, China and the US (M. Faure \& J. Hu (eds.), The Hague: Kluwer Law International, 2006).

Shan H. \& Zhang J. The Civil Liability Regime for Vessel Source Oil Pollution in China, 15 Journal of International Maritime Law 340 (2009).

Tsimplis M.N. The Bunker Pollution Convention 2001: Completing and Harmonizing the Liability Regime for Oil Pollution From Ships?, 1 Lloyd's Maritime \& Commercial Law Quarterly 83 (2005).

Zhang L. Comparative Study on Compulsory Insurance of Oil Pollution by Marine Oil Development and by Ships, 149 Journal of Henan University of Economics \& Law 31 (2015). 
Zhu L. Probing Compulsory Insurance for Maritime Liability, 45(1) Journal of Maritime Law \& Commerce (2014).

\section{Information about the author}

Dinh Thi My Linh (Moscow, Russia) - PhD Student, Department of Civil Law and Procedure and International Private Law, Law Institute, Peoples' Friendship University of Russia (6 Miklukho-Maklaya St., Moscow, 117198, Russia; e-mail: linh.vboice94@ gmail.com). 